\title{
Estimasi Ketebalan Lapisan Sedimen dan Amplifikasi Desa Olak Alen Blitar Menggunakan Metode Mikrotremor HVSR
}

\author{
Nomensen M. H. Sitorus, M. Singgih Purwanto, S.Si,MT, dan Dr. Widya Utama, DEA \\ Departemen Teknik Geofisika, Fakultas Teknik Sipil dan Perencanaan, Institut Teknologi Sepuluh \\ Nopember (ITS) \\ e-mail: m.singgih.purwanto@gmail.com
}

\begin{abstract}
Abstrak-Tanah longsor yang terjadi di Desa Olak Alen Blitar pada Desember 2016 berada di lokasi dengan lapisan sedimen yang tebal (>30meter). Lapisan sedimen yang tebal dan berasosiasi dengan kemiringan lereng yang tinggi sangat rentan terhadap potensi gerakan tanah. Selain itu faktor perbesaran perambatan gelombang (Amplifikasi) yang semakin tinggi juga akan meningkatkan resiko terjadinya gerakan tanah. Oleh karena itu telah dilakukan pengukuran mikrotremor dengan metode HVSR di Desa Olak Alen. Melalui metode HVSR akan diperoleh nilai amplifikasi dan frekuensi natural dari kurva $H / V$. Berdasarkan nilai frekuensi natural dan N-SPT dari data bor dihitung nilai ketebalan sedimen. Ketebalan lapisan sedimen Desa Olak Alen berkisar antara 17,03 - 221,39 meter dengan nilai amplifikasi antara 1,3 - 6,2. Longsor yang terjadi di Desa Olak Alen berada di lokasi dengan ketebalan lapisan sedimen 5287 meter dan nilai amplifikasi 4,1 - 5,7.
\end{abstract}

Kata Kunci-Ketebalan sedimen, amplifikasi, frekuensi natural, HVSR.

\section{PENDAHULUAN}

L ONGSOR merupakan gerakan menuruni lereng oleh massa tanah dan atau batuan penyusun lereng, akibat dari terganggunya kestabilan tanah atau batuan penyusun lereng tersebut. Desa Olak Alen berada di Kecamatan Selorejo, Kabupaten Blitar. Bencana tanah longsor terjadi di Desa OlakAlen pada tanggal 2 Desember 2016. Hal ini diperkirakan diakibatkan oleh curah hujan yang sangat tinggi dan lama mulai beberapa hari sebelum terjadinya longsor. Selain itu lokasi longsor ini juga tepat berada di daerah dengan kelerengan yang cukup tinggi.

Secara umum topografi di sekitar lokasi gerakan tanah berupa perbukitan bergelombang dengan ketinggian lebih dari $390 \mathrm{~m}$ dpl. Daerah bencana termasuk zona potensi terjadi gerakan tanah menengah Berdasarkan Peta Prakiraan Potensi Terjadi Gerakan Tanah pada Bulan Desember 2016 di Kabupaten Blitar, Provinsi Jawa Timur yang diterbitkan oleh badan geologi. Zona potensi gerakan tanah menengah artinya apabila pada daerah ini terjadi curah hujan diatas normal, terutama pada daerah yang berbatasan dengan lembah sungai, gawir, tebing jalan dan lereng akan mengakibatkan gerakan tanah. Karena berada pada zona menengah maka dapat disimpulkan bahwa potensi terjadinya gerakan tanah di daerah ini cukup besar dengan kondisi curah hujan tinggi.

Pada suatu daerah yang mengalami longsor cenderung berada pada daerah yang memiliki lapisan sedimen lebih tebal yang berasosiasi dengan kondisi topografi lebih tinggi daripada arah longsorannya. Maka untuk mengetahui ketebalan sedimen suatu daerah dilakukan pengukuran mikrotremor. Metode yang digunakan adalah metode HVSR dengan tujuan memperoleh kurva $\mathrm{H} / \mathrm{V}$. Metode ini merupakan metode yang membandingkan antara rasio spektrum dari sinyal mikrotremor komponen horizontal terhadap komponen vertikalnya. Dari kurva $\mathrm{H} / \mathrm{V}$ kemudian akan didapatkan 2 parameter penting yang merepresentasikan kondisi geologi pada daerah tersebut. Kedua parameter ini adalah amplifikasi dan frekuensi natural. Frekuensi natural sangat berkaitan erat dengan ketebalan lapisan lapuk/sedimen dan nilai kecepatan perambatan gelombangnya.

\section{METODOLOGI PENELITIAN}

Pengukuran mikrotremor dilakukan di Desa Olak Alen, Kecamatan Selorejo, Kabupaten Blitar. Terdapat 55 titik pengukuran yang dilakukan dengan spasi sekitar 200-300 meter. Data lapangan hasil pengukuran kemudian diolah menggunakan metode HVSR dengan alur seperti pada gambar 1. Pengolahan ini bertujuan untuk mendapatkan rasio spectrum horizontal to vertical $(\mathrm{H} / \mathrm{V})$ yang kemudian akan dilakukan analisis dan perhitungan sampai diperoleh nilai kerentanan tanah. Data mentah yang diperoleh dari pengukuran lapangan berupa tiga komponen sinyal dalam fungsi waktu. Kemudian ketiga sinyal tersebut dilakukan proses picking yang bertujuan untuk memilih data atau untuk menghilangkan noise yang terekam. Setelah itu dilakukan transformasi fourier (FFT) pada masing-masing komponen sinyal yang telah di picking.

Kemudian dilakukan proses smoothing atau filtering. Smoothing dilakukan karena hasil dari proses FFT masih berupa komponen yang belum halus. Maka digunakan filter smoothing Konno dan Ohmachi dengan koefisien bandwith 40 dan cosine taper 5\%. Setelah proses smoothing selesai maka dilakukan penggabungan komponen horizontal dan vertikal ke dalam analisis HVSR. Selanjutnya rata-rata spektrum HVSR diplot untuk setiap titik pengukuran setelah diperoleh spektrum HVSR masing-masing window. Dari analisis HVSR akan diperoleh kurva $\mathrm{H} / \mathrm{V}$ yang menunjukkan nilai frekuensi natural (f) dan amplifikasi (A). Kemudian dari nilai frekuensi Gambar 1. Alur Pengolahan Data Mikrotremor HVSR. 


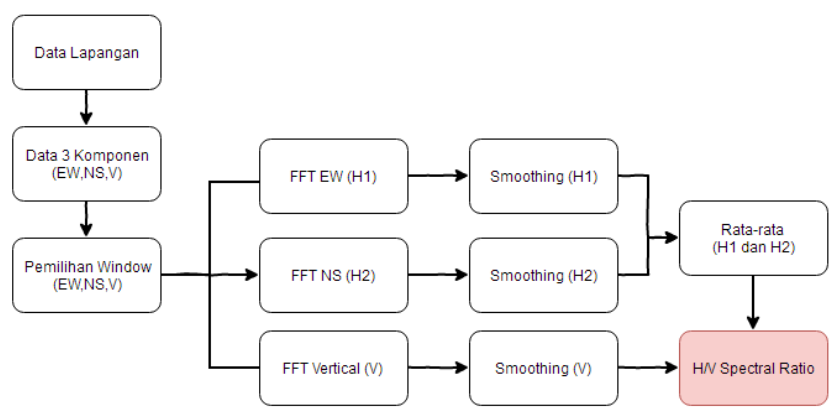

natural dan nilai N-SPT dapat dihitung ketebalan lapisan sedimen. N-SPT diperoleh dari hasil data bor yang dilakukan di Desa Olak Alen.

\section{HASIL DAN DISKUSI}

Hasil pengolahan data mikrotremor dengan metode HVSR ini bersifat subjektif, oleh karena itu untuk menentukan apakah kurva $\mathrm{H} / \mathrm{V}$ tersebut sudah baik dan dapat benar benar diakui keakuratannya maka digunakan kriteria yang telah ditetapkan oleh SESAME European Research Project. Setelah diperoleh kurva $\mathrm{H} / \mathrm{V}$ yang reliable maka diperoleh nilai amplifikasi dan frekuensi naturalnya.

\section{A. Faktor Amplifikasi}

Faktor amplifikasi dipengaruhi oleh kecepatan gelombang, apabila kecepatan gelombang semakin kecil maka faktor amplifikasi semakin besar, hal ini menunjukkan bahwa faktor amplifikasi berhubungan dengan tingkat kepadatan batuan, dimana berkurangnya kepadatan batuan akan meningkatkan nilai faktor amplifikasi. Hal ini disebabkan oleh sedimen lunak yang memperlambat durasi gelombang yang menjalar di daerah tersebut, sehingga terjadi goncangan terhadap bangunan, begitu juga sebaliknya (Hartati, 2014). Nilai amplifikasi di Desa Olak Alen adalah 1,3 - 6,2. Klasifikasi nilai amplifikasi dalam Setiawan, 2009 dinyatakan seperti pada tabel 1.

Tabel 1.

Klasifikasi Nilai Amplifikasi (Setiawan, 2009)

\begin{tabular}{ccc}
\hline \hline Zona & Klasifikasi & Nilai Faktor Amplifikasi \\
\hline 1 & Rendah & $\mathrm{A}<3$ \\
2 & Sedang & $3 \leq \mathrm{A}<6$ \\
3 & Tinggi & $6 \leq \mathrm{A}<9$ \\
4 & Sangat Tinggi & $\mathrm{A} \geq 9$ \\
\hline \hline
\end{tabular}

Berdasarkan nilai amplifikasi yang diperoleh pada setiap titik pengukuran maka dibuat peta persebaran nilai amplifikasi pada gambar 2.

\section{B. Ketebalan Lapisan Sedimen}

Berdasarkan kurva $\mathrm{H} / \mathrm{V}$ yang diperoleh telah diketahui nilai frekuensi natural pada daerah tersebut. Kemudian untuk mencari nilai ketebalan lapisan sedimen dilakukan perhitungan dari nilai frekuensi natural dan nilai N-SPT. SPT merupakan tes penetrasi tanah yang dilakukan untuk mengetahui jenis tanah di lokasi dengan melakukan bor. Sebelum menghitung ketebalan sedimen terlebih dahulu dihitung nilai kecepatan gelombang gesernya (Vs).

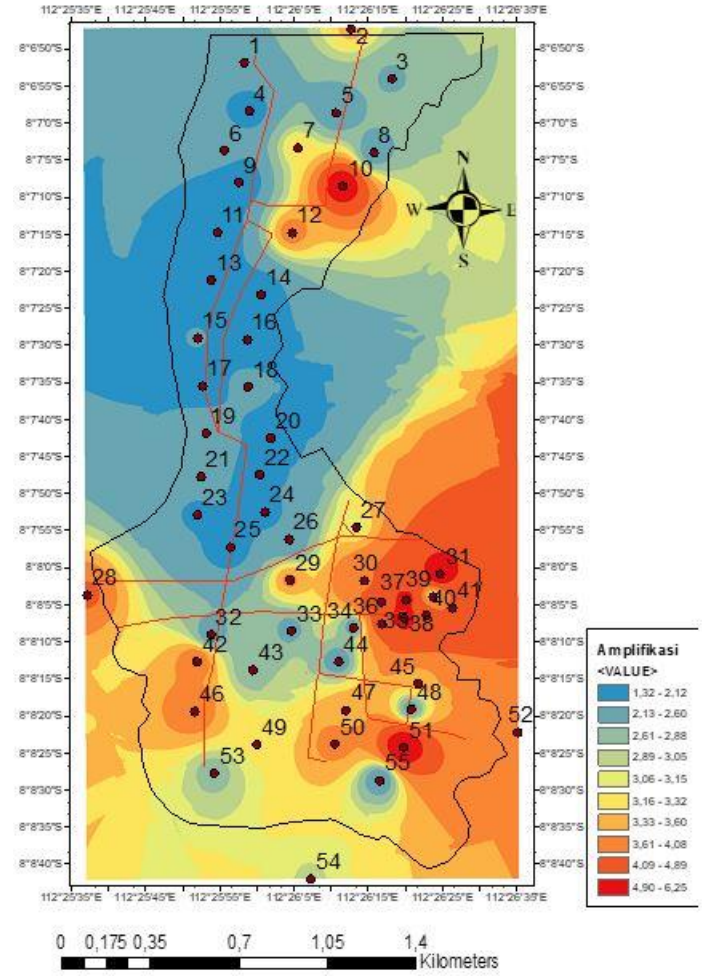

Gambar 2. Peta Persebaran nilai amplifikasi Desa Olak Alen.

Banyak peneliti yang telah mengembangkan korelasi antara nilai N-SPT dan kecepatan gelombang geser (Vs) untuk berbagai jenis tanah. Berdasarkan data borehole litologi pada daerah penelitian berupa pasir kelanauan (silty sand) sampai kedalaman 30 meter. Oleh karena itu pada penelitian ini pendekatan Vs digunakan persamaan Hanumantharao \& Ramana (2008) untuk silty sand atau sand silt sebagai berikut:

$$
V_{s}=86,0 N^{0,42} \frac{m}{s}
$$

Kemudian setelah nilai Vs setiap kedalaman diketahui maka kemudian dicari nilai exponential faktor (X) dengan persamaan 2 sebagai berikut:

$$
V_{s}(z)=V_{0}(1+Z)^{X}
$$

Dengan Vs (Z) merupakan kecepatan gelombang geser pada kedalaman (Z). Dan $\mathrm{V}_{\mathrm{o}}$ merupakan kecepatan gelombang permukaan. $\mathrm{Z}$ merupakan kedalaman dan $\mathrm{X}$ merupakan exponential factor. Kemudian dapat dihitung ketebalan lapisan sedimen menggunakan persamaan 3 berikut:

$$
m=\left[\frac{V_{0}(1-X)}{4 f r}+1\right]^{\frac{1}{(1-X)}}-1
$$

Dengan m merupakan ketebalan/kedalaman bedrock. Dan $\mathrm{V}_{\mathrm{o}}$ merupakan kecepatan gelombang permukaan. fr adalah frekuensi dominan dan X sebagai exponential factor. Maka berdasarkan perhitungan yang telah dilakukan pada 55 titik pengukuran diperoleh peta kontur nilai ketebalan sedimen pada gambar 3. 


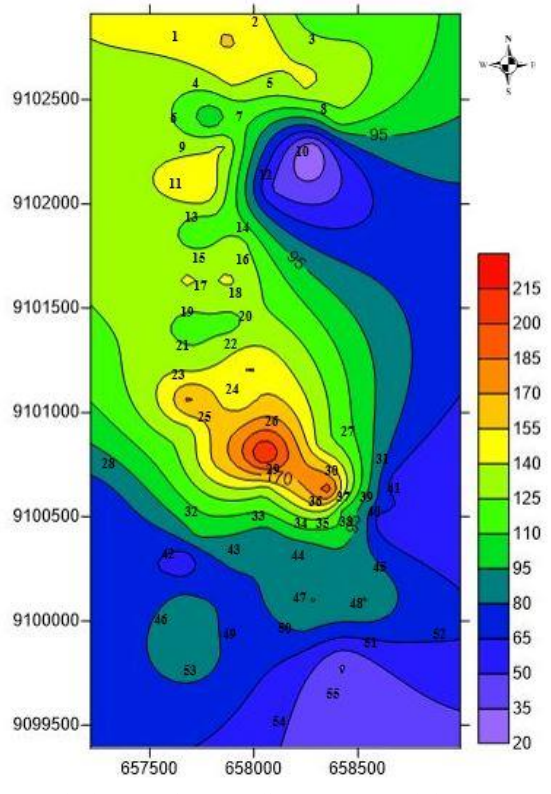

Gambar 3. Peta Ketebalan Lapisan Sedimen Desa Olak Alen.

\section{Analisis Longsor}

Longsor yang terjadi di Desa Olak Alen pada bulan Desember 2016 berada di sekitar titik pengukuran 38 - titik pengukuran 41. Berdasarkaan nilai ketebalan sedimennya dapat dilihat pada daerah tersebut berada pada nilai sekitar 5287 meter. Alhasanah, 2006 menyatakan bahwa tanah longsor identik dengan kondisi kemiringan lereng. Dengan kata lain longsor akan terjadi pada daerah dengan elevasi yang lebih tinggi dengan arah longsoran ke daerah yang memiliki elevasi yang lebih rendah. Oleh karena itu dibuat peta kontur elevasi desa olak alen seperti pada gambar 4.

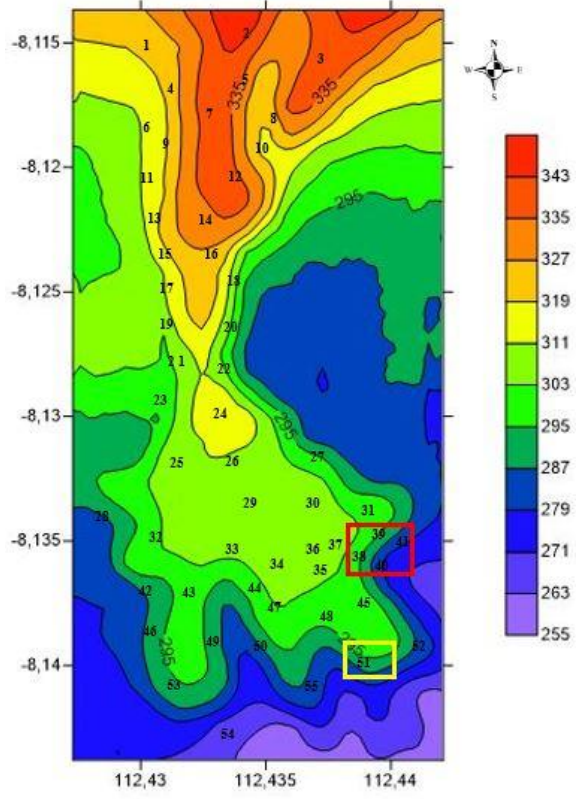

Gambar 4. Peta Kontur Elevasi Desa Olak Alen.

Daerah longsor ditandai dengan kotak merah pada gambar 4. arah pergerakan tanah adalah ke arah tenggara. Hal ini sesuai dengan kondisi topografi yang semakin rendah ke arah tenggara. Selain itu pada daerah longsor ini juga diperoleh nilai amplifikasi yang cukup tinggi. Berdasarkan klasifikasi oleh Setiawan, 2009 nilai amplifikasi di TP 38-41 termasuk ke dalam kategori sedang. Sehingga dapat disimpulkan bahwa daerah yang rawan terhadap adanya potensi gerakan tanah adalah daerah yang memiliki lapisan sedimen yang tebal ( $>30$ meter ) dengan kemiringan lereng yang tinggi serta berasosiasi dengan nilai amplifikasi sedang-tinggi. Berdasarkan analisis tersebut maka diprediksi di daerah TP 51 yang ditandai dengan kotak kuning pada gambar 4 memiliki potensi akan mengalami pergerakan tanah ke arah selatan.

\section{KESIMPULAN}

\section{A. Simpulan}

Berdasarkan hasil dan pembahasan pada bab sebelumnya, kesimpulan dari penelitian ini adalah sebagai berikut:

1) Ketebalan lapisan sedimen Desa Olak Alen antara 17,03 meter - 221,39 meter.

2) Longsor di Desa Olak Alen berada pada daerah dengan nilai ketebalan sedimen 52-87 meter dengan arah longsoran ke arah tenggara serta berasosiasi dengan nilai amplifikasi sedang-tinggi dengan nilai 4,1 -5,7

\section{B. Saran}

Saran dari hasil penelitian ini adalah sebagai berikut:

1) Dapat dilakukan pengukuran kembali saat musim kemarau karena nilai fisis lapisan tanah yang dapat berubah dengan kondisi saat musim penghujan.

2) Ketebalan lapisan sedimen yang diperoleh valid dengan korelasi yang dilakukan terhadap hasil data bor sehingga hasil penelitian ini dapat dipercaya apabila dibutuhkan dalam penentuan lokasi bangunan

\section{DAFTAR PUSTAKA}

[1] Gosar, A. 2007. Microtremor HVSR Study for Assesing Site Effects in the Bovec Basin (NW Slovenia) Related to $1998 \mathrm{Mw} 5.6$ and $2004 \mathrm{Mw}$ 5.2 Earthquake. ELSEIVER Engineering Gelogy 91

[2] Nakamura. 1998. A Method for Dynamic Characteristic Estimation of Subsurface Using Microtremor on the Ground Surface. Q.R. of R.T. 30(1): 25-33.

[3] SESAME. 2004. Guidelines For The Implementation Of The H/V Spectral Ratio Technique on Ambient Vibrations. Europe: SESAME Europen research project.

[4] Setiawan J.R. 2009. Mikrozonasi Seismitas Daerah Yogyakarta Dan Sekitarnya. Tesis. Bandung: Institut Teknologi Bandung.

[5] Winoto, Prasetyo. 2010. Analisis Mikrotremor Kawasan Universitas Brawijaya Berdasarkan Metode HVSR. Thesis. Malang : Universitas Brawijaya.

[6] Hartati, Lidia. 2014. Pemetaan Tingkat Resiko Gempabumi Daerah Liwa dan Sekitarnya Berdasarkan Pengukuran Mikrotremor. Thesis. Yogyakarta : UGM. 